\title{
Religious disagreement: An empirical study among academic philosophers
}

\author{
Helen De Cruz
}

Department of Philosophy, VU University Amsterdam, h.l.de.cruz@vu.nl

This is the version after peer review, prior to copy-editing of a paper accepted at Episteme, A journal of individual and social epistemology.

\begin{abstract}
Religious disagreement is an emerging topic of interest in social epistemology. Little is known about how philosophers react to religious disagreements in a professional context, or how they think one should respond to disagreement. This paper presents results of an empirical study on religious disagreement among philosophers. Results indicate that personal religious beliefs, philosophical training, and recent changes in religious outlook have a significant impact on philosophers' assessments of religious disagreement. They regard peer disagreement about religion as common, and most surveyed participants assume one should accord weight to the other's opinion. Theists and agnostics are less likely to assume they are in a better epistemic position than their interlocutors about religious questions compared to atheists, but this pattern only holds for participants who are not philosophers of religion. Continental philosophers think religious beliefs are more like preferences than analytic philosophers, who regard religious beliefs as fact-like.
\end{abstract}

Keywords: religious disagreement, experimental philosophy of religion, epistemic peer disagreement.

\section{Introduction}

Religious disagreement is salient; even people who live in relatively homogeneous religious communities are aware that many do not agree with the religious views they hold. Religious testimony often implies potential sources of disagreement, for instance, a Mormon father who says to his children "We Latter-Day Saints believe that Jesus is our brother, sent to us by 
Heavenly Father," is signaling that not all religious believers share this view, and indirectly that non-Mormons are likely to disagree. Thus, even young children come to realize that disagreement prevails on just about any religious topic. By contrast, they notice consensus about scientific facts, perhaps with the exception of politicized topics, such as evolution, vaccination, and climate change (Harris et al. 2006, Harris \& Corriveau 2014).

One emerging topic of interest in the social epistemology of religion is how we should respond to religious disagreement. How should one react when confronted with someone who holds religious beliefs that are doxastically incompatible with one's own beliefs? A difficult case is when one assumes that the dissenting other is an epistemic peer, roughly, someone who is, on balance, in an equally good epistemic position compared to oneself. In such a situation, should one become less confident about one's beliefs, or suspend judgment altogether (e.g., Feldman 2007)? Or is it permissible to accord more weight to one's own beliefs than to those of others (e.g., van Inwagen 2010)? These questions fit in a broader discussion on epistemic peer disagreement, a debate often phrased in generalized abstract terms (see e.g., the essays collected in Christensen \& Lackey 2013). Reasoning from particular cases, such as disagreement about the outcome of a mental calculation (e.g., splitting the bill in a restaurant), epistemologists hope to attain a generalized appropriate response to disagreement, regardless of its contents.

Using the method of cases, it becomes evident that the topic of disagreement influences intuitions about what the most appropriate response might be: conciliating is recommended when one ends up with different results of a calculation, but it is less clear whether one should revise one's beliefs in the case of religious, political, or ethical disagreement. Religious disagreement has particular features (see e.g., Frances 2014, for discussion): it occurs on a large scale, typically involves many-on-many rather than one-onone dissent, is sustained over long periods of time, and most people seem to feel little pressure to change their religious views when they learn that others disagree about them.

Most work on religious disagreement (e.g., Feldman 2007, van Inwagen 2010, Lackey 2014) relies on standard philosophical tools, such as conceptual analysis and the method of cases, but some authors also make 
empirical claims. For instance, Pittard (2014) proposes that religious believers, even those who are moderate conciliationists ${ }^{1}$ have little reason to revise their views in religious disagreements. Purportedly, this is because religious belief systems "include controversial claims about what qualifies one to reliably assess religious propositions", and most "religious theories of epistemic credentials are at least minimally self-favoring” (Pittard 2014, 85). This leads to the prediction that religious believers are more likely to find themselves in a better epistemic position, and that they are less likely to conform to the opinions of others in religious matters. Frances (2014) surmises that philosophers judge they are in a better epistemic position, rather than in a peer disagreement, when confronted with religious disagreement: theists might think they are in a better position because they have access to religious experiences unavailable to nontheists, while atheists might suspect their believing colleagues are subject to wishful thinking, groupthink, and other uncongenial cognitive processes. Although claims like these have some prima facie plausibility, they have until now not been subject to empirical investigation.

In this paper I present findings from a survey on religious disagreement aimed at academic philosophers. What do philosophers think about religious disagreement? Do they think these debates take place with epistemic peers, and what criteria do they use to assess who is an epistemic peer? I examine whether religious belief, gender, philosophical specialization, and experience, play a role in these assessments. My choice for these predictors is informed by the subject matter-it is plausible that religious beliefs might influence how one regards religious disagreement-and by earlier work in experimental metaphilosophy, which has focused on gender (Buckwalter \& Stich 2014), philosophical specialization (e.g., Bourget \& Chalmers 2014) and expertise (e.g., Schwitzgebel \& Cushman 2015). These are presumably not the only factors that might influence the appraisal of philosophers of religious disagreement, and future work in experimental

\footnotetext{
${ }^{1}$ Moderate conciliationists (e.g., Christensen 2011) hold that disagreement with an epistemic peer should lead one to revise one's belief.
} 
metaphilosophy might uncover other factors that influence how philosophers think about religious disagreement.

\section{Methodology}

Philosophers were recruited through philosophy blogs (NewApps, Prosblogion, The Philosophers' Cocoon), and a philosophy mailing list (Philos-L). In the call, I specified the target population as academic philosophers, that is, holders of a PhD in philosophy or current philosophy graduate students. The study was conducted online with Qualtrics. All survey questions are listed in the appendix.

\section{Results}

\subsection{Descriptive statistics of the participants}

In the course of November and December 2014, 518 philosophers completed the survey. $77.6 \%$ of respondents were male, $20.7 \%$ female, and $1.5 \%$ other. The gender distribution of women in this sample is in line with what we find in philosophy departments in the $\mathrm{US}^{2}$. Participants hailed from several geographical locations, the majority from English-speaking countries: the United States (48.3\%), the United Kingdom (15\%), Canada (7.2\%), and Australia (3.7\%). Most respondents outside of the English-speaking world came from Germany (5.4\%). The average age of respondents was 37.5 years $(\mathrm{SD}=12.1$ years $)$.

Respondents were graduate students (35.7\%), faculty members with tenure or an equivalent status (28.7\%), tenure-track faculty members (9.7\%), non-tenure track faculty, such as postdocs, visiting assistant professors, fixedterm lecturers (15.7\%), adjuncts and other part-time instructors (4.5\%), philosophers employed outside of academia (3.5\%), and unemployed (2.3\%). The most frequently mentioned academic specializations were ethics (35.3\%), epistemology (27.6\%), metaphysics (26.1\%), history of philosophy (24.1\%), philosophy of religion (23\%), philosophy of science (22.4\%), philosophy of

\footnotetext{
${ }^{2}$ In the US, $22.2 \%$ of philosophers in tenure-track or tenured positions at the top-50 doctoral schools are female (data of 1 January 2015, http://web.csulb.edu/ jvancamp/doctoral_2004.html).
} 
mind (19.3\%), political philosophy (17.8\%), and philosophy of language $(15 \cdot 3 \%)^{3}$.

\subsection{The religious beliefs of philosophers}

Participants were asked about their current religious belief (question 1), and given the choice between theism, atheism, agnostic/undecided, or another view. A slight majority of respondents were atheists (50.2\%), followed by theists (25.5\%), agnostics (16.4\%), and holders of other views (7.9\%). This latter category is quite heterogeneous; here is a selection of responses:

"Ignostic: I think that someone metaphysical exists, but it is not possible to describe it in human language"

"Effectively: atheist; strictly: Russellian teapot-agnostic"

"Some kind of pantheism or panentheism"

"Spiritual, but not a classical theist"

"Agnostic in conversation, atheist in private"

"Non-traditional theism (i.e., in which God is taken to be multiple, material, etc.)"

The percentage of atheists in this sample is lower than in Bourget and Chalmers' (2014) PhilPapers survey, which had 72.8\% atheists, 14.6\% theists, and $12.6 \%$ other (probably encompassing agnostics and other views). This difference might be due to self-selection: since the present survey focuses on religious disagreement, it may have attracted more philosophers who had an interest in religion, and who are thus more likely to be theists, agnostics, or non-traditional religious believers. But the lower percentage of atheists in this study might also in part reflect a more diverse demographic of faculty members and students in the present survey, compared to Bourget and Chalmers' study. Their target respondents were faculty members in leading PhD granting departments, thus excluding less prestigious schools. Sociological studies suggest that atheism is more prevalent among elite than among non-elite institutions (see e.g., Gross \& Simmons 2009), and that

3 The total adds up to more than 100\% because many philosophers have more than one area of specialization. 
atheism is more prevalent among academics than among the general population, though not as high as in Bourget and Chalmers' study4.

The theists in this sample are regular attenders of religious services (question 3). Of the philosophers who are theists $(\mathrm{N}=130)$, only $.8 \%$ never attend religious services, $6.9 \%$ do so rarely, $9.2 \%$ a few times a year, $3.8 \%$ about once a month, $13.8 \%$ a few times a month, $43.1 \%$ once a week, and 22.3\% more than once a week.

In line with other surveys among professional philosophers (e.g., Bourget \& Chalmers 2014, De Cruz \& De Smedt in press), there is a positive correlation between theism and philosophy of religion as an area of specialization $(\mathrm{r}=.258, \mathrm{p}<.001)$. In this sample, theists are disproportionately represented among philosophers of religion (60.5\%). 10.1\% have another view, and there are comparably fewer atheists and agnostics in philosophy of religion (22.7\% and 6.7\% respectively) compared to philosophy as a whole. Among the participants who are not philosophers of religion, $15 \%$ are theists, $58.4 \%$ atheists, $19.3 \%$ agnostics/undecided, and $7.3 \%$ have another view.

Given that most respondents did not report a change in their religious beliefs-only $17.6 \%$ had experienced a significant change in religious outlook since graduate school (question 2)-this high representation of theists in philosophy of religion is probably a result of self-selection. If one assumes theism to be true, philosophy of religion is a central area of philosophical research, but if one thinks theism is false, philosophy of religion is of similar importance as philosophical investigations into other cultural practices, such as the philosophy of music or sports.

\footnotetext{
${ }^{4}$ Even Ecklundt and Scheitle (2007), who focused on 21 elite, researchintensive US institutions, reported a higher percentage of theists (37\%) among academics. In Gross and Simmons' (2009) more diverse sample (which included some religious liberal arts colleges), the percentage of theists was $55.8 \%$. This suggests that more surveying is needed, across a wide range of institutions, to get an accurate picture of the percentage of atheists in philosophy.
} 


\subsection{What constitutes an epistemic peer in the religious domain?}

Epistemologists have proposed several views on what counts as an epistemic peer. For instance, Gutting (1982) described epistemic peers in terms of intellectual virtues such as attentiveness, intelligence, and thoroughness. In recent discussions, philosophers have emphasized evidential equality, i.e., epistemic peers have access to the same evidence (e.g., Christensen 2007), or have proposed that epistemic peers are equally likely to be wrong (e.g., Elga 2007).

To examine what criteria philosophers consider most important for epistemic peerhood, participants were asked what they considered the most important factor in deciding whether someone is an epistemic peer in a religious disagreement (question 6). They were offered the choice between an epistemic virtues account, an evidence account, a probability to be right or wrong account, or another view. The majority of respondents thought virtues were the most important factor, followed by evidence (see Table 1).

This finding indicates that most philosophers favor a concept of epistemic peerhood that predates the more recent evidence-based accounts. Intellectual virtues trump evidential equality when it comes to being an epistemic peer, at least in the religious domain. (In future studies, it would be interesting to find out whether philosophers find evidence more important in other fields.)

\begin{tabular}{|l|l|}
\hline $\begin{array}{l}\text { You are equally epistemically virtuous (thoughtful, attentive, etc.) } \\
\text { in considering the religious claims in question }\end{array}$ & $60 \%$ \\
\hline $\begin{array}{l}\text { You have access to the same evidence about the religious claims in } \\
\text { question }\end{array}$ & $17 \%$ \\
\hline $\begin{array}{l}\text { You think you and the other philosopher(s) are equally likely to be } \\
\text { wrong about the religious claims in question }\end{array}$ & $12 \%$ \\
\hline Something else (please specify). & $11 \%$ \\
\hline
\end{tabular}

Table 1: What constitutes an epistemic peer? 


\subsection{How often are disagreements about religion between epistemic peers?}

Philosophers disagree about a variety of issues, such as meta-ethical, political, and epistemological questions. For instance, van Inwagen reflects on the fact that he disagrees with Lewis on whether free will and determinism are incompatible and on some other philosophical topics:

How can I believe (as I do) that free will is incompatible with determinism or that unrealized possibilities are not physical objects or that human beings are not four-dimensional things extended in time as well as in space, when David Lewis-a philosopher of truly formidable intelligence and insight and ability-rejects these things I believe and is already aware of and understands perfectly every argument that I could produce in their defense (van Inwagen 1999, 274)?

Clearly, van Inwagen considers Lewis as an epistemic peer in some sense, but yet he asserts:

I am confident that I am right. But how can I take these positions? I don't know. That is itself a philosophical question, and I have no firm opinion about its correct answer. I suppose my best guess is that I enjoy some sort of philosophical insight ... that, for all his merits, is somehow denied to Lewis (van Inwagen 1999, 274).

At least in some respects, van Inwagen considers himself an epistemic superior to Lewis concerning these questions. More recently, he rejects this earlier conclusion, proposing that he and Lewis are epistemic peers on the compatibilism question:

I can only conclude that I am rational in accepting incompatibilism and that David was rational in accepting compatibilism. And, therefore, we have at least one case in which 
one philosopher accepts a philosophical proposition and another accepts its denial and in which each is perfectly rational (van Inwagen 2010, 24).

Other authors (e.g., Frances 2010) have argued that philosophers who continue to defend and believe a view they know is not shared widely among philosophers can be blameless in adhering to these beliefs. For instance, the disagreement could be rooted in an undefended assumption, or some factor that is irrelevant to one's philosophical perspicacity, such as one's religious upbringing. Such factors can be used as symmetry breakers that make it rational not to consider the others as peers.

How often do philosophers consider colleagues to be their peers if they express a religious view that is incompatible with their own beliefs (question 4)? Respondents answered on a seven-point scale, ranging from "never" to "always" (Fig. 1). Results show that philosophers regard religious peer disagreement as relatively common, with only a minority of respondents reporting that they rarely or never encounter an epistemic peer. This indicates that philosophers do not by default assume they are in a better epistemic position about religious matters.

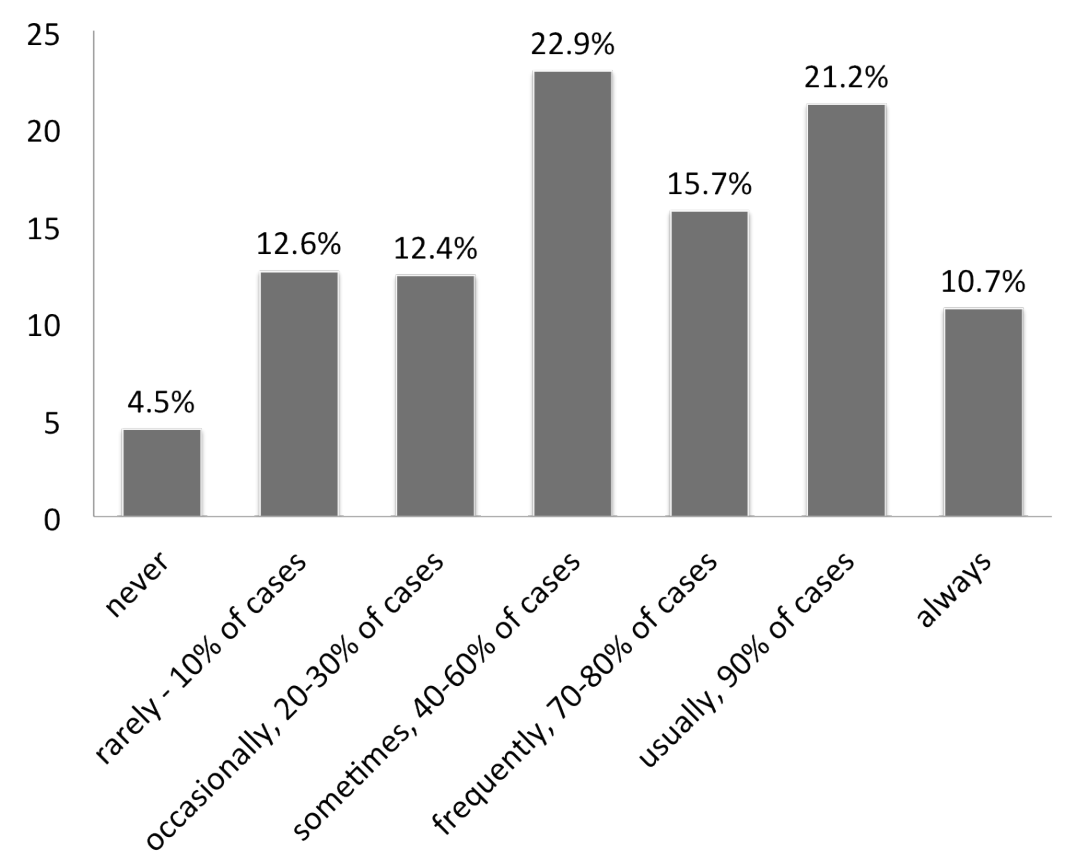

Figure 1: Perceived frequency of encountering epistemic peers in philosophical discussions on religious matters. 
Philosophy of religion often centers on specialized topics, such as divine foreknowledge or the possibility of free will in Heaven. One might expect that scholars who frequently discuss religious topics with other specialists would encounter a higher frequency of interlocutors who are intellectually and evidentially matched when the topic is religion than philosophers who do not have this specialization, i.e., they would report a higher frequency of peer disagreement. This prediction was confirmed: the median response for philosophers of religion was "frequently, in $70-80 \%$ of cases", whereas the median response for philosophers without this specialization was "sometimes, in 40-60\% of cases". A Mann-Whitney test for independent samples revealed that this difference was significant, albeit with a small effect size $(\mathrm{N}=518, \mathrm{U}=20218.5, \mathrm{p}=.022, \mathrm{r}=.10)$.

Interestingly, people who underwent significant changes in their religious beliefs (question 2) were also more likely to encounter epistemic peers. $17.6 \%$ of respondents experienced significant changes in their religious beliefs since graduate school, i.e., since they took up advanced training in philosophy5. The percentage of atheists reporting religious conversions (10.4\%) was significantly lower than the percentage of theists (24.2\%), agnostics (75.9\%), and non-traditional believers (24.4\%) who converted. Here is a sample of the responses (drawn from theists, atheists, agnostics, and nontraditionalists) about the nature of their religious conversion:

"I have gradually become (i) more open to the idea of an existing ultimate reality and (ii) convinced of the importance of thinking about this question."

"From theism to atheism."

"When I began graduate school in 2005, I was a theist. Now I am agnostic about God's existence."

"I have become increasingly committed to naturalism and decreasingly sympathetic to supernaturalism."

"I have gotten more skeptical of religious claims, but not for any good reason. Mainly because of who my peers are."

5 As one of the referees pointed out, there may be a potential ambiguity in how this is interpreted, either as the start or end of one's period in graduate school. 
"During and after graduate school, I transitioned from a moreor-less typical form of American Evangelicalism to a less conservative and more historically-rooted version of Christianity. Perhaps I could still be described as an Evangelical, but the shift in my views is (from my perspective) very significant."

"I considered myself a militant atheist before grad school. Now I'm just an atheist."

"I was an atheist when I entered graduate school, and a theist when I finished."

Philosophers who experienced a significant change in religious outlook encountered epistemic peers more frequently than those who did not. Upon closer inspection, it turns out that this effect was solely driven by atheists. Atheists who had changed their religious outlook since graduate school reported significantly more instances of epistemic peer disagreement than unwavering atheists $(\mathrm{N}=259, \mathrm{U}=3.893, \mathrm{p}=.036, \mathrm{r}=.13)$.

\subsection{What to do when confronted with an epistemic peer?}

Respondents were asked what they thought one should do when confronted with disagreement with an epistemic peer in general (question 7), and what to do in a religious disagreement (question 8). For both questions, respondents could choose between conciliationism/conformism: you are required to accord weight to your peer's attitude, steadfastness/nonconformism: you are not required to accord weight to your peer's attitude, and another view, which they could specify.

For the general case, the majority of respondents (54.1\%) regarded conciliationism as the proper attitude, $23.7 \%$ selected a steadfast position, and 22.2\% opted for another view. The latter include:

"There is no generally appropriate reaction (no way to tell in advance whether to hold fast or change your beliefs)." "The belief that $\mathrm{p}$ has the burden of proof; the sceptical belief (not-p) does not. If I hold that $\mathrm{p}$, I accord as much weight to the peer's attitude as my burden of proof requires." 
"It depends. In some cases (as Christensen's check-splitting cases) it is rationally obligatory to conciliate. But not all cases are like this."

“If an epistemic peer doesn't say what I would say, I presume a high probability that I don't understand her (or vice versa)."

"Inquire into their evidential base. Figure out whether they use words in the same way as I do. Figure out whether they're being disingenuous or self-deceived."

There was a high consistency between responses for the general and the religious case $(\mathrm{r}=.691, \mathrm{p}<.001) .40 .2 \%(\mathrm{~N}=205)$ of respondents were conciliationists for both cases, $21.8 \%$ were steadfasters for both situations ( $\mathrm{N}$ = 111), $16.9 \%(\mathrm{~N}=86)$ preferred another view for both. The remaining respondents had differing answers for the general scenario and the religious case. Only $1.4 \%(\mathrm{~N}=7)$ of respondents thought that steadfastness was in general the best attitude and that conciliationism was appropriate for the religious case. By contrast, $8.6 \%(\mathrm{~N}=44)$ of respondents thought that while conciliationism was the most appropriate response in general, religious disagreements require a steadfast position. To examine whether this is a significant difference, I performed a McNemar's test for paired categorical variables, focusing on philosophers who responded either "conciliationism" or "steadfastness" on the question of general cases, and comparing their answers to the religious case. The number of people who chose conciliationism-general and steadfast-religion $(\mathrm{N}=44)$ was significantly higher than the number of philosophers who picked steadfast-general and conciliationism-religion $(\mathrm{N}=7)$, $(\mathrm{p}<.001, \mathrm{r}=.26)$.

This suggests that philosophers do have differing intuitions about religious cases as opposed to idealized, generalized scenarios. In particular, a significant percentage of philosophers think one should generally accord weight to one's peers' beliefs, but see a steadfast attitude as more appropriate for religious cases.

\subsection{Who is in a better epistemic position?}

Peer disagreement is a specific instance of disagreement, where the dissenting parties are assumed to be evidential and cognitive equals. However, in many 
cases there is an asymmetry between the dissenters, for instance, when a climate-change denying politician discounts the informed opinion of a climate scientist. Also, real-world cases are messy where disagreeing parties can have advantages in one domain (e.g., having considered the question with more care than the other party) but disadvantages in other domains (e.g., not having access to the same body of evidence). Still, in many cases, one can be, all things considered, in a better epistemic position compared to someone else. For example, although I may be more thoughtful in considering a hard mathematical puzzle, a professional mathematician will be, all things considered, in a better epistemic position compared to me when it comes to solving the puzzle.

As we have seen, philosophers take it they are sometimes involved in disagreements with epistemic peers, but for the remaining instances they believe there is an asymmetry. When such an asymmetry occurs, who is in the better epistemic position (question 5)? The options were: (1) In the majority of cases I am in a better epistemic position, (2) In the majority of cases, they are in a better epistemic position, (3) In about half of the cases, it's them, in the other half it's me.

Unsurprisingly, and in line with research that indicates that most adults, including highly educated ones, are prone to an "above average" illusion (see e.g., Elga 2005), a majority of respondents (71.1\%) supposed they were mostly in a better epistemic position, $26.5 \%$ assumed they were in the better position half of the time, $2.4 \%$ gathered the other was usually in a better position.

Does religious belief make a difference in how epistemically modest respondents are? For the purposes of this paper, respondents who chose options 2 or 3 are labeled as "epistemically modest" 6 . One could predict (e.g.,

\footnotetext{
${ }^{6}$ I use the term "epistemic modesty" as convenient shorthand, without moral considerations that the term might suggest, e.g., that epistemic modesty would always be preferable to epistemic immodesty. Moreover, there is no single definition for the term epistemic modesty; for instance, Christensen (2013) regards willingness to revise one's beliefs in the face of peer
} 
Pittard 2014) that theists, because they adhere to religious beliefs that have their own epistemological criteria of acceptance, would be less epistemically modest. On the other hand, given that atheism is the dominant position in philosophy (and in academia as a whole), more theists might exhibit epistemic modesty than atheists, who might draw confidence from adhering to the majority opinion. Moreover, there is a widespread idea among atheists (New atheists come to mind) that theists have their views because they are irrationally influenced by indoctrination or emotional factors. While some theists think that atheists are subject to irrational influences or defective faculties (e.g., Plantinga 2000), it would seem that the former idea is more widespread and provides an easy route to downgrade the epistemic positions of those with whom one disagrees.

Theists might be involved in different religious debates than atheists, for instance, about whether Hell exists or about which concept of the Trinity is correct. By contrast, when atheists-with the exception of atheist philosophers of religion-debate religion, this seems to mainly concern the basic question of whether naturalism or theism is correct, a question where one might feel more confident one is right than about subtle theological points. If this is the case, theists might find themselves more frequently in debates where they are less likely to feel in an epistemically better position, which predicts that fewer atheists would be epistemically modest.

Overall, theists, atheists, agnostics, and adherents to other beliefs differed in how often they thought they were in an epistemically better position in religious discussions, $X^{2}(6, \mathrm{~N}=457)=33.4, \mathrm{p}<.001$, Cramer's $\mathrm{V}$ $=$.19. After Bonferroni correction, the following responses remained significant: theists responded less frequently that they were in an epistemically better position than atheists $(\mathrm{p}<.01)$; a similar pattern was observed for agnostics $(\mathrm{p}<$.001). Theists were more likely to respond that they were correct in half of cases $(\mathrm{p}<.01)$ compared to atheists, as were agnostics compared to atheists $(\mathrm{p}<.01)$. There were no significant pairwise differences between those who held another view and any of the other

disagreement as one form of epistemic modesty. In this paper, I do not regard conciliationism as such. 
positions. Atheists responded more frequently than expected that they were correct in the majority of cases $(\mathrm{p}<.001)$ and less frequently that they were correct in half of cases $(\mathrm{p}<$.001) compared to theists and agnostics. Figure 2 summarizes these findings. These results provide evidence against Pittard's (2014) prediction that theists would be less epistemically modest, or less inclined to accord weight to the views of others, because they have epistemic systems that set peculiar criteria for acceptance and that are self-validating.

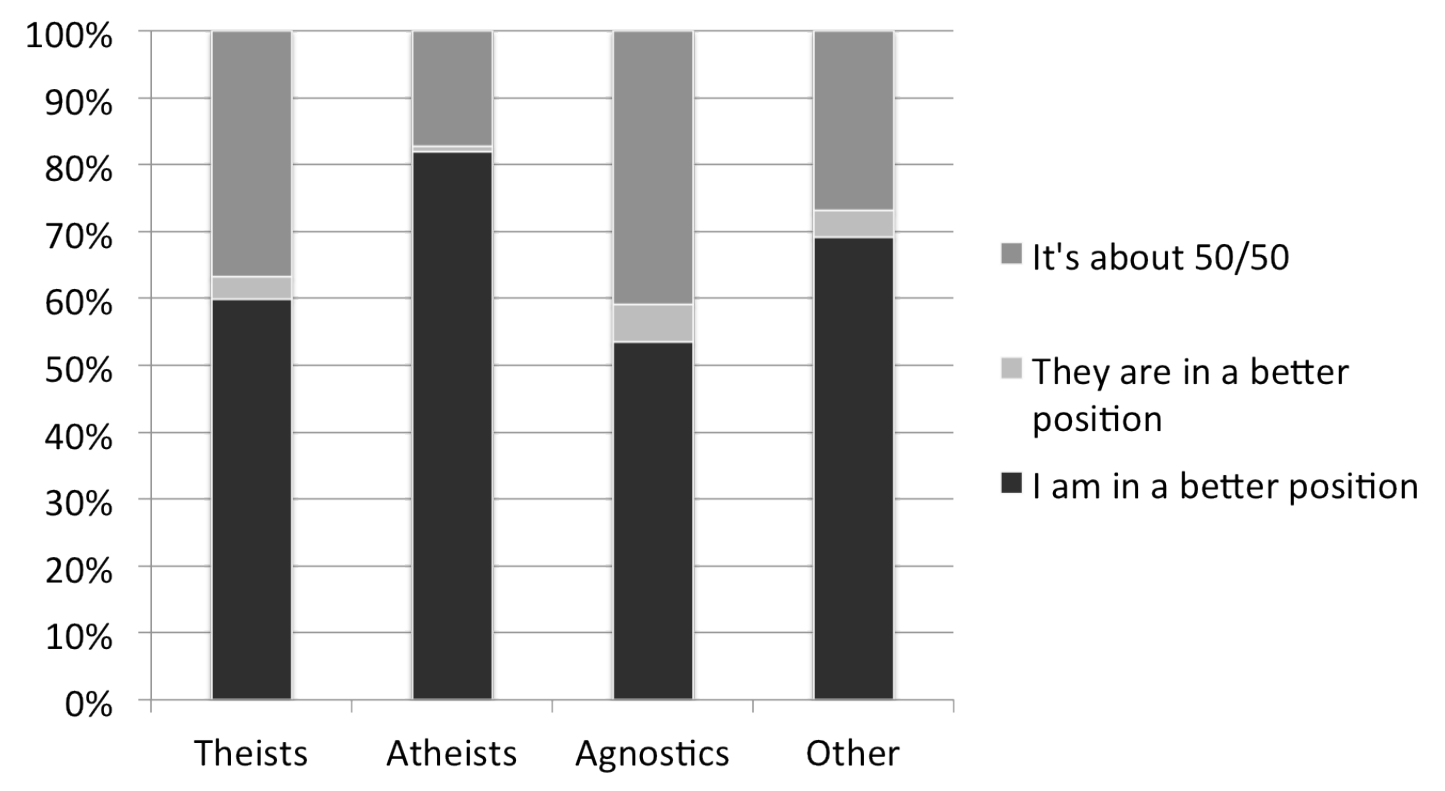

Figure 2: When there is a difference, who is in a better position?

Why are fewer atheists in the sample epistemically modest in situations of religious disagreements than theists and agnostics? To recall, the main hypotheses that predict this result are that atheists think religious believers are epistemically defective, that atheists are in a majority in philosophy and academia more generally, and that atheists feel more confident about the (general) topics they disagree about, as they rarely discuss detailed theological matters. To examine the plausibility of these hypotheses, I compared philosophers of religion with philosophers who do not have this specialization. As this study illustrates (in line with Bourget \& Chalmers 2014), the majority of philosophers of religion are theists, whereas the majority of other philosophers are atheists. Thus, one would expect-if majority opinion played a role-that fewer theists in philosophy of religion would be epistemically modest than theists in other philosophical disciplines. However, if the effect is 
driven by the ambit of discussions philosophers engage in, one would fine more epistemic modesty in atheist philosophers of religion than in atheists in other philosophical disciplines.

A closer examination of philosophers of religion found that the lower frequency of epistemic modesty among atheists may be driven by the nonphilosophers of religion: there is no significant difference in epistemic modesty between theists, atheists, agnostics, and non-traditionalists among philosophers of religion $\left(X^{2}(6, \mathrm{~N}=105)=10.10, \mathrm{p}=.120\right.$, Cramer's $\left.\mathrm{V}=.219\right)$. By contrast, among non-philosophers of religion, significantly more atheists responded they were in a better position than theists and agnostics $\left(X^{2}(6, \mathrm{~N}=\right.$ $352)=22.29, \mathrm{p}=.001$, Cramer's $\mathrm{V}=.178)$. While this finding is tentative, and would need to be replicated with a larger sample (especially given the similar effect sizes in both samples), this suggests that taking part in specialized debates on religion (which atheist philosophers of religion do more frequently than atheists who do not have this specialization) might account for differences in epistemic modesty between theists and atheists. Confidence elicited through majority opinion likely is not a causal factor, because one would then expect that theist philosophers of religion would be less epistemically modest than atheist philosophers of religion, given the preponderance of theists in philosophy of religion.

To confirm that it is the distance between the positions that each party defends that makes a difference, one would have to examine whether theists respond as often as atheists that they are in a better position if they have a large disagreement with someone else (say, a discussion about whether God exists, rather than a discussion about the merits of open theism). In future work, a fine-grained experimental study that presents different forms of religious disagreements (between people who have many or few points of agreement) could help to clarify this. Additionally, future work could uncover whether smaller or larger perceived disagreements in general correspond to differences in epistemic modesty.

\subsection{No expertise or gender effects}

There is a debate on whether philosophical expertise leads to different intuitions (e.g., Rini 2015, Schwitzgebel \& Cushman 2012, De Cruz 2015). I 
examined whether more experienced philosophers have views on religious disagreement that differ from those of less experienced philosophers. To draw the sharpest contrasts, I compared tenured faculty (the most experienced group) to graduate students (the least experienced group), and to the remaining participants ${ }^{7}$. There were no expertise effects: tenured faculty members did not respond significantly differently from graduate students or other philosophers.

I reran the analysis by dividing the participants into different age groups (under 30, 31-40, 41-50, 51-60, and 61 and over), since there is no perfect correlation between experience and academic position, and some participants may have significant experience while not having attained a high academic rank. There was a moderate correlation between age and academic rank $(\mathrm{r}=.432, \mathrm{p}<$.001). Also when using age as the independent variable, there were no significant expertise effects.

While some authors (e.g., Buckwalter \& Stich 2014) have argued gender plays a role in the assessment of philosophical ideas, others have failed to replicate their findings (Seyedsayamdost 2015). I examined whether women and men responded significantly differently from each other. I did not find gender effects for any of the dependent variables ${ }^{8}$.

\subsection{If you disagree about religious matters, can you both be right?}

Some authors (e.g., van Leeuwen 2014) have argued that religious credences lack properties that are characteristic of factual belief. One distinguishing element of factual beliefs, such as scientific statements, is that two people who hold incompatible beliefs about them cannot both be right, for instance, if Sam believes "Dinosaurs only lived a long time ago" and Pat thinks "There are dinosaurs alive right now 9 ," people tend to believe that one of them is wrong. By contrast, in preference cases, such as when Maria thinks green is the

7 Postdocs, tenure-track professors, adjuncts, people employed outside of academia, or unemployed were grouped together in one heterogeneous category.

8 The number of philosophers who self-identified as another gender was too small to make robust statistical inferences.

9 Prompt of a scientific belief in Heiphetz et al. (2013), 564. 
prettiest color and Lena favors blue, people tend to think that both dissenters can be right.

Heiphetz et al. (2013) examined whether 5-to-10 year olds and adults thought religious beliefs were more like factual claims (if people disagree at least someone must be wrong) or like preference claims (both can be right). For example, they presented interlocutors who either believed "God knows all of our thoughts" or "Only we know all of our thoughts." Adults and children judged claims of religious doctrine and faith to be in between fact and preference: they thought that people who uttered religious claims could sometimes both be right, but not as often as in preference cases.

To examine whether philosophers regard religious beliefs as more factlike or more preference-like, I presented participants with a scenario of religious disagreement"10 (question 9): “Jesse thinks there is a god, and Tim thinks there is no god, is it possible for both of them to be right?" $72.7 \%$ thought it was impossible that both are right, $18.4 \%$ believed it was possible that both are right, and the remaining $8.9 \%$ were not sure. Philosophers seem to predominantly regard religious beliefs as fact-like rather than preferencelike. By comparison, in the study by Heiphetz and colleagues, about $60 \%$ of adults responded that both could be right in matters of religious doctrine, compared to only $20 \%$ who responded that both could be right about factual statements. Philosophers thus seem to differ from the general population in viewing religious beliefs as more fact-like. This may be a result of philosophical training, especially in analytic philosophy, which regards philosophical propositions (in particular, metaphysical propositions) as having a definite truth-value, and their methodology as science-like (see e.g., Trakakis 2007, 198). By contrast, continental philosophers would be less concerned with truth claims and subjecting religious beliefs to thought experiments and other tests. This leads to the prediction that analytic

\footnotetext{
10 Originally, there was an additional question: "Kathryn thinks there is one god, and Larissa thinks there are many gods. Is it possible for both of them to be right?" This question was not analyzed because some respondents reported that they could interpret the question in more than one way (i.e., one god could mean "at least one god" or "only one god").
} 
philosophers regard religious claims as more fact-like than continental philosophers.

To test this hypothesis, I examined differences between analytic philosophers and philosophers from other traditions (continental, nonwestern, history of philosophy) on this question. I found a significant effect of continental philosophy as an area of specialization, $X^{2}(2, \mathrm{~N}=510)=17.19, \mathrm{p}$ $<.001$, Cramer's V = .18. Posthoc tests with Bonferroni corrections for multiple comparisons reveal that continental philosophers $(\mathrm{N}=67)$ were more likely to think that both could be right (37.3\% of continental philosophers) than philosophers who were not working in the continental tradition $(\mathrm{N}=443)$, only $16.5 \%$ of whom thought both could be right. A similar effect size was observed for philosophers who study nonwestern philosophical traditions ( $\mathrm{N}=28$ ), where $46.4 \%$ of respondents believed it is possible for both to be right, compared to $17.6 \%$ of philosophers who do not specialize in nonwestern traditions $(\mathrm{p}<.001$, Cramer's V = .19).

There are no other significant differences for philosophical specialization on this question when controlling for multiple comparisons. Non-significant trends with small effect sizes were observed for historians of philosophy (N=125), who were more likely to answer "yes", p =.002, Cramer's $\mathrm{V}=.11$, which was not significant after controlling for multiple comparisons. The same was true for epistemologists $(\mathrm{N}=143)$, with a slightly lower likelihood of answering "yes" (12\% of epistemologists), versus $22 \%$ of nonepistemologists, $\mathrm{p}=.002$, Cramer's $\mathrm{V}=.16$, not significant after Bonferroni correction. Figure 3 provides a summary. 


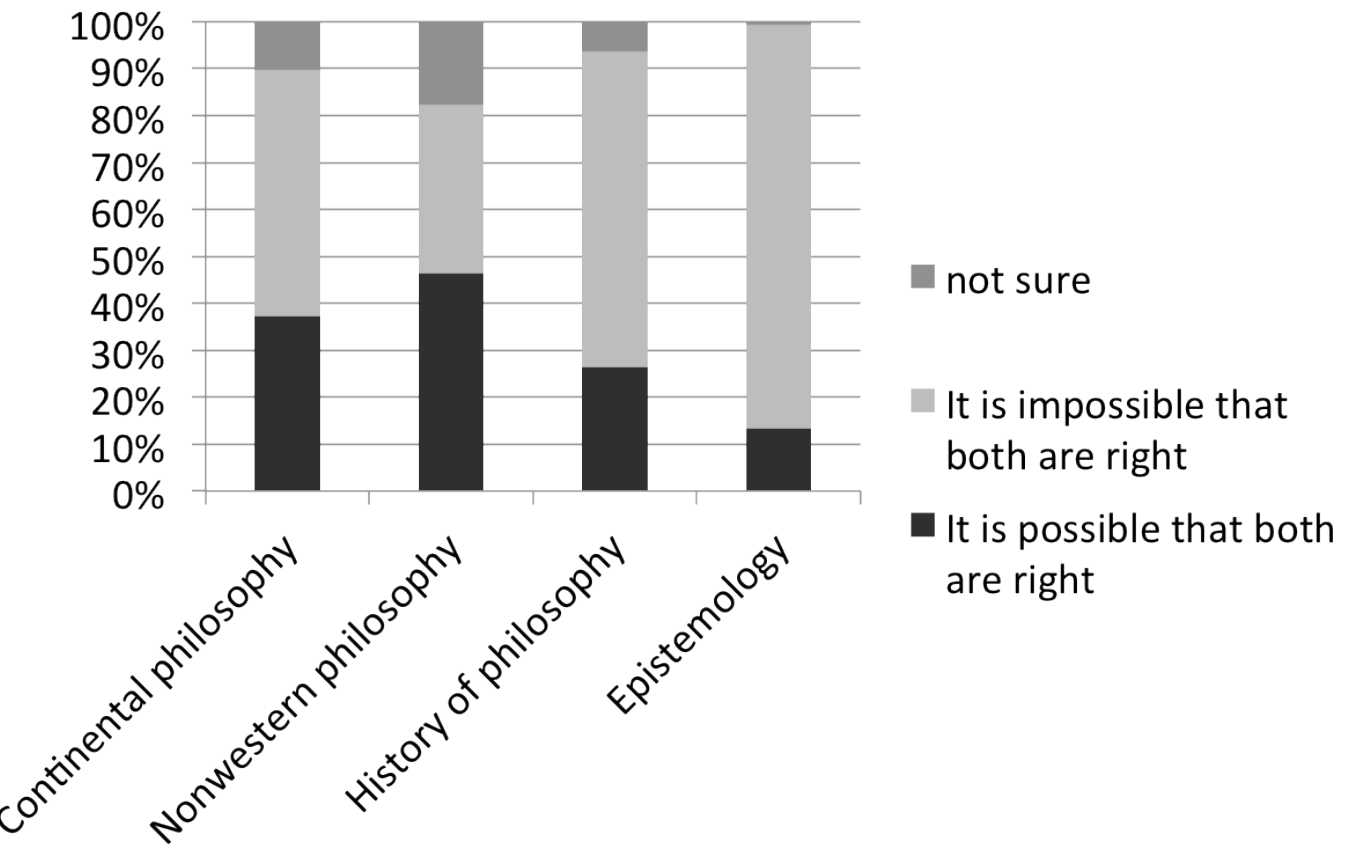

Figure 3: Differences between continental philosophers, philosophers specializing in nonwestern philosophical traditions, historians of philosophy and epistemologists on whether two people can both be right in a religious disagreement.

Different religious outlooks also resulted in differences in the extent to which philosophers think incompatible religious beliefs can both be right, $X^{2}$ $(6, N=510)=34.15, p<.001$, Cramer's $V=.191$. Atheists are significantly less likely than agnostics and non-traditionalists to affirm it is possible that both are right $(13.6 \%$ of atheists, $\mathrm{p}<.01)$, whereas agnostics are less likely than theists and atheists to state it is impossible that both are right $(56.6 \%$ of agnostics, $\mathrm{p}<.01)$. Non-traditionalists are more likely than theists and atheists to choose, "yes, it is possible that both are right" $(43.6 \%, \mathrm{p}<.001)$, and significantly less frequently to tick "it is impossible that both are right" $(56.6 \%, \mathrm{p}<.001)$. Figure 4 shows these differences, indicating that people who identify with a non-traditional religious outlook hold a more preferencelike view of religious beliefs compared to traditional theists and atheists. These results indicate that agnostics and non-traditionalists see religious beliefs significantly more as preference-like compared to theists and atheists. Since atheists believe that religious beliefs are false, it is perhaps not surprising that they hold the most fact-like view of religious beliefs. 


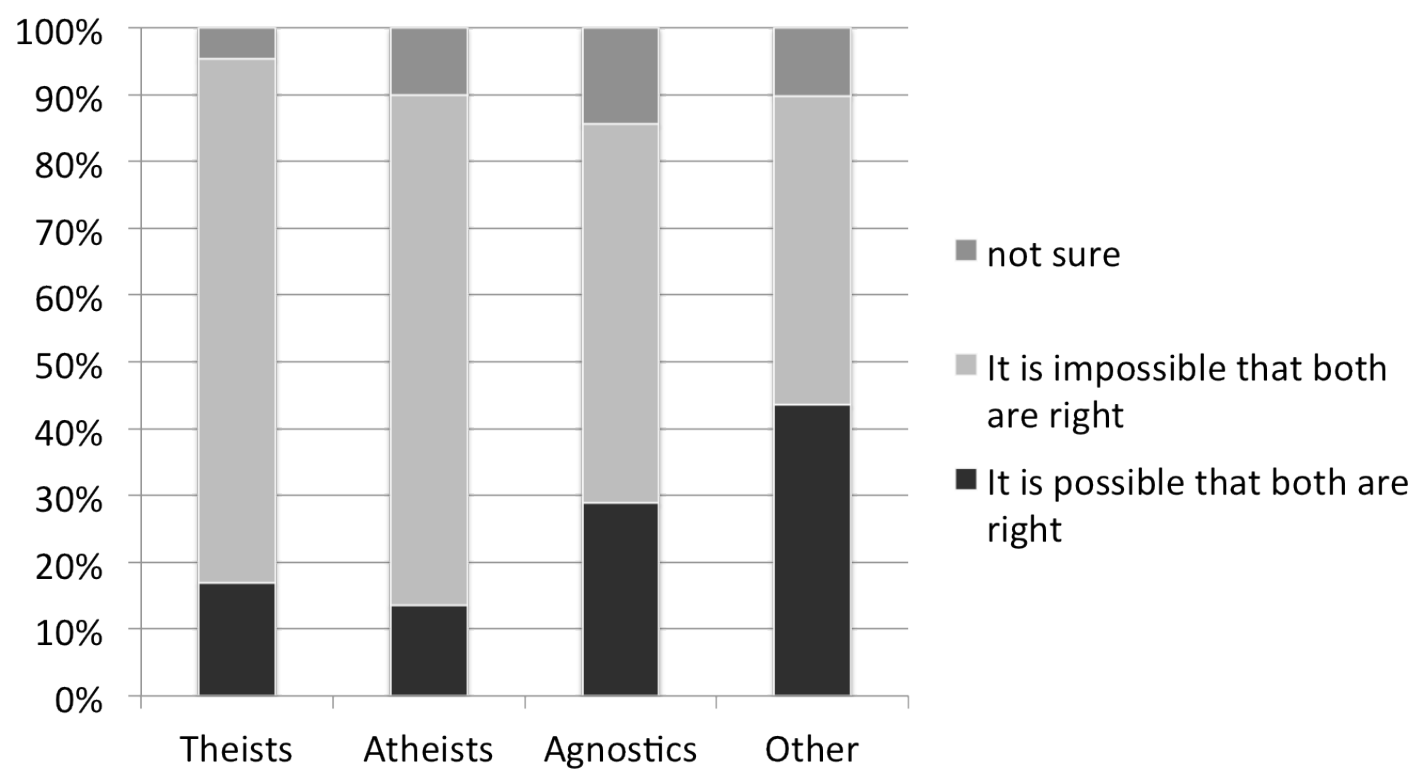

Figure 4: Differences between atheists, theists, agnostics, and nontraditionalists (Other) on whether religious beliefs are preference-like (It is possible that both are right) or fact-like (It is impossible that both are right).

\section{Conclusions}

This paper presents findings from a survey on religious disagreement among philosophers. My main findings can be summarized as follows. Personal beliefs (religious background), personal changes in religious attitude since graduate school, and philosophical specialization influence the views of philosophers on religious disagreement. In their professional experience, philosophers held that disagreements on religious matters frequently take place between epistemic peers (about 40-60\% of cases). Philosophers found epistemic virtues such as thoughtfulness and attentiveness more important for epistemic peerhood (60\%) than having access to the same evidence (17\%), or an equal likelihood of being wrong (12\%).

Theists found themselves more frequently in debates with epistemic peers on religious matters than atheists, but atheists who had experienced significant changes in religious outlook since graduate school were also more likely to consider others as epistemic peers in religious debates.

When confronted with a disagreement with an epistemic peer, most philosophers judged that one should accord weight to the views of that person (conciliationism, 54.1\%), while 23.7\% recommended steadfastness. Although 
most respondents thought that the appropriate response in a religious disagreement does not differ from other cases, a significant minority believed it was permissible to remain steadfast in a religious disagreement, while recommending conciliationism in general.

Peer disagreement is just one instance of disagreement, and often there is an asymmetry between the dissenting parties. When this is the case for a religious disagreement, most philosophers $(71.1 \%)$ believed they were in a better epistemic position in the majority of cases. Among philosophers in general, theists and agnostics were more epistemically modest than atheists. But in philosophy of religion, atheists, theists, and agnostics are equally epistemically modest. The scope of debates on religion (which is larger among theists than among atheists, and larger in philosophy of religion compared to other philosophical disciplines) may incline philosophers to be more epistemically modest.

I also examined what philosophers think about the nature of religious beliefs: do they see religious beliefs as more fact-like, where a disagreement means that at least one of the dissenting parties is wrong, or as more preference-like, where both can be right? I found that philosophers, unlike adults from the general population, think predominantly of religious beliefs as fact-like in nature. Philosophical specialization has an influence on this assessment: continental philosophers and philosophers who specialize in nonwestern traditions indicated more frequently that both parties can be right in a dispute about religious doctrine. This suggests that the tendency of analytic philosophers to regard philosophical views as continuous with the sciences has an impact on how analytic philosophers appraise religious statements.

\section{Acknowledgments}

This research was supported by a postdoctoral grant of the British Academy (grant pf130006). I would like to thank all the philosophers who participated to this survey. The study was given ethical clearance by the University of Oxford's Central University Research Ethics Committee. Many thanks to David Christensen, Joshua Knobe, Johan De Smedt, Brent Strickland, Elisa

Freschi, Amber Griffioen, Stewart Guthrie, Andrea Hollingsworth, Richard 
Irvine, Kevin Tobia, H.E. Baber, Clayton Littlejohn, Tim Kenyon, Dennis Potter, Claire White, Jinzhou Ye, Josh Reeves, two anonymous referees, and an associate editor of Episteme for comments to an earlier version of this paper.

\section{Appendix - list of questions}

1. Which of the following best describes your current religious belief? Theism, Atheism, Agnostic or undecided, Another view (please specify) [optional textbox entry]

2. Since your time in graduate school, did your religious outlook change substantially? No/Yes (please specify) [optional textbox entry]

3. How often do you attend religious services? Never, Rarely, A few times a year, About once a month, A few times a month, Once a week, More than once a week

4. When you read or hear the views of another philosopher on religious matters, if this philosopher holds a position that is incompatible with yours (e.g., if you are an atheist and the philosopher in question is a theist), how often do you consider them to be your epistemic peer? (Never, Rarely - in 10\% or less of cases, Occasionally - in $20-30 \%$ of cases, Sometimes - in about $40-$ $60 \%$ of cases, Frequently - in about $70-80 \%$ of cases, Usually - in about $90 \%$ of cases, Always)

5. [this question does not appear if "Always" is selected in answer to question 4] In matters of religious disagreement with other philosophers whom you do not consider as your epistemic peers, who do you think is in a better epistemic position? (In the majority of these instances, I am in a better epistemic position, In the majority of these instances, they are in a better epistemic position, In about half of these instances, they are in a better position, in the other half, it's me) 
6. In matters of religious disagreement, which of the following factors do you think is most relevant for deciding whether someone is an epistemic peer? (You have access to the same evidence about the religious claims in question, You are equally epistemically virtuous (thoughtful, attentive, etc) in considering the religious claims in question, You think you and the other philosopher(s) are equally likely to be wrong about the religious claims in question, Something else (please specify) [optional textbox entry])

7. Generally speaking, if you believe that $p$, and you are confronted with someone you consider your epistemic peer who believes not-p, how should you react? (Conciliationism/conformism: you are required to place at least some weight to your peer's attitude, Steadfast position/nonconformism: you are ${ }^{*}$ not* $^{*}$ required to place at least some weight to your peer's attitude, Another view (please specify) [optional textbox entry])

8. In a religious disagreement, such as about the existence of God, if you are confronted with someone you consider your epistemic peer who disagrees with you, how should you react? (Conciliationism/conformism: you are required to place at least some weight to your peer's attitude, Steadfast position/nonconformism: you are *not* required to place at least some weight to your peer's attitude, Another view (please specify) [optional textbox entry])

9. Jesse thinks there is a god, and Tim thinks there is no god. Is it possible for both of them to be right? (Yes, it is possible for both of them to be right, No, it is impossible for both of them to be right, Not sure)

10. Kathryn thinks there is one god, and Larissa thinks there are many gods. Is it possible for both of them to be right? (Yes, it is possible for both of them to be right, No, it is impossible for both of them to be right, Not sure)

11. What is your age (in years)? [textbox]

12. What is your gender? (male, female, other) 
13. In what country to you reside? [list of countries]

14. What are your areas of specialization (select all that apply)? [list of philosophical specializations]

15. What is your academic position? (Graduate student or other student, Tenure-track faculty member, Tenured or permanent faculty member, Nontenure track full-time faculty member (e.g., postdoc, VAP), Adjunct or other part-time teaching position, Employment outside of academia, Unemployed)

\section{References}

Bourget, D. \& Chalmers, D.J. (2014). What do philosophers believe? Philosophical Studies, 170, 465-500.

Buckwalter, W. \& Stich (2014). Gender and philosophical intuition. In: J. Knobe and S. Nichols (Eds), Experimental Philosophy. Vol. 2 (pp. 307-316). Oxford: Oxford University Press.

Christensen, D. (2007). Epistemology of disagreement: The good news. Philosophical Review, 116, 187-217.

Christensen, D. (2011). Disagreement, question-begging and epistemic selfcriticism. Philosopher's Imprint, 11, 1-22.

Christensen, D. (2013). Epistemic modesty defended. In D. Christensen \& J. Lackey (Eds.), The epistemology of disagreement: New essays (pp. 77-97). Oxford: Oxford University Press.

Christensen, D. \& Lackey, J. (Eds.) (2013). The epistemology of disagreement: New essays. Oxford: Oxford University Press.

De Cruz, H. (2015). Where philosophical intuitions come from. Australasian Journal of Philosophy, 93, 233-249. 
De Cruz, H., \& De Smedt, J. (in press). How do philosophers evaluate natural theological arguments? An experimental philosophical investigation. In: H. De Cruz \& R. Nichols (Eds.), Advances in Religion, cognitive science, and experimental philosophy. London: Continuum.

Ecklund, E.H., \& Scheitle, C.P. (2007). Religion among academic scientists: Distinctions, disciplines, and demographics. Social Problems, 54, 289-307.

Elga, A. (2005). On overrating oneself ... and knowing it. Philosophical Studies, 123, 115-124.

Elga, A. (2007). Reflection and disagreement. Noûs, 41, 478-502.

Feldman, R. (2007). Reasonable religious disagreements. In L. Anthony (Ed.), Philosophers without gods (pp. 194-214). Oxford: Oxford University Press.

Frances, B. (2010). The reflective epistemic renegade. Philosophy and Phenomenological Research, 81, 419-463.

Frances, B. (2014). Disagreement. Cambridge: Polity Press.

Gross, N. \& Simmons, S. (2009). The religiosity of American college and university professors. Sociology of Religion, 70, 101-129.

Gutting, G. (1982). Religious belief and religious skepticism. Notre Dame, IN: University of Notre Dame Press.

Harris, P.L., Pasquini, E.S., Duke, S., Asscher, J.J., \& Pons, F. (2006). Germs and angels: The role of testimony in young children's ontology. Developmental Science, 9, 76-96. 
Harris, P.L., \& Corriveau, K.H. (2014). Learning from testimony about religion and science. In E. Robinson \& S. Einav (Eds.), Children's trust in testimony (pp. 28-41). Hove: Psychology Press.

Heiphetz, L., Spelke, E. S., Harris, P. L., \& Banaji, M. R. (2013). The development of reasoning about beliefs: Fact, preference, and ideology. Journal of Experimental Social Psychology, 49, 559-565.

Lackey, J. (2014). Taking religious disagreement seriously. In: L.F. Callahan \& T. O’Connor (Eds.), Religious Faith and intellectual virtue (pp. 299-316). Oxford: Oxford University Press.

Pittard, J. (2014). Conciliationism and religious disagreement. In: M. Bergmann \& P. Kain (Eds.), Challenges to moral and religious belief. Disagreement and evolution (pp. 80-97). Oxford: Oxford University Press.

Plantinga, A. (2000). Warranted Christian belief. New York: Oxford University Press.

Rini, R.A. (2015). How not to test for philosophical expertise. Synthese, 192, 431-452.

Schwitzgebel, E. \& Cushman, F. (2015). Philosophers' biased judgments persist despite training, expertise and reflection. Cognition, 141, 127-137.

Schwitzgebel, E. \& Cushman, F. (2012). Expertise in moral reasoning? Order effects on moral judgment in professional philosophers and non-philosophers. Mind \& Language, 27, 135-153.

Seyedsayamdost, H. (2015). On gender and philosophical intuition: Failure of replication and other negative results. Philosophical Psychology, 28, 642-673.

Trakakis, N. (2007). Meta-philosophy of religion: The analytic-continental divide in philosophy of religion. Ars Disputandi, 7, 179-220. 
van Inwagen, P. (1999). Is it wrong everywhere, always, and for anyone to believe anything on insufficient evidence? In E. Stump \& M.J. Murray (Eds.), Philosophy of religion (pp. 273-284). Blackwell.

van Inwagen, P. (2010). We're right. They're wrong. In R. Feldman and T.A. Warfield (Eds.), Disagreement (pp. 10-28). Oxford: Oxford University Press.

van Leeuwen, N. (2014). Religious credence is not factual belief. Cognition, $133,698-715$. 